\title{
Reform and Exploration of Electric Machinery Course Under the Background of Engineering Professional Education Certification
}

\author{
Xiaojuan Zhang ${ }^{1, *}$, Jie Zhang ${ }^{1}$, Hongbo Li $^{1}$, Yukun Qiao ${ }^{1}$ \\ ${ }^{1}$ College of Science, Xijing University, Xi'an, Shaanxi, 710123, China \\ *Corresponding author. Email: hansi-321@163.com
}

\begin{abstract}
Under the professional certification of engineering education and the talent training needs of cultivating virtues and morality, engineering professional courses lack the humanistic environment and humanistic spirit compared with other courses. It is necessary to analyze the ideological and political elements of traditional engineering professional courses. This article takes the course of "Electric Machinery" for electrical majors as an example, reorganizes the course content, excavates ideological and political elements, constructs ideological and political content, reforms teaching models and methods, and carries out course ideological and political practice. In the course of knowledge transfer and ability training, ideological and political education is carried out subtly, so that professional education and core value education can be integrated together, so as to achieve the organic unity of "knowledge transfer" and "value guidance", and realize the education function of professional courses.

Keywords: New engineering, professional certification, electrical engineering, curriculum ideology
\end{abstract}

\section{INTRODUCTION}

For a long time, our country has put the ideological and political education of college students in the first place. At the National University Ideological and Political Conference held in December 2016, General Secretary Xi Jinping proposed that we should insist on establishing morality as the central link of education, integrating ideological and political work throughout the whole process of education and teaching, and realizing the whole process of educating people and full-member, all-round education. The strategic goal of full-member, full-process, and all-round education (referred to as the "Three-Allround Education") puts forward higher requirements for the development of higher education in the new era [1]. In February 2017, the Department of Higher Education of the Ministry of Education officially launched the "New Engineering" construction plan (excellent engineer education and training technology version 2.0), and successively formed the "Fudan Consensus", "Tianda Action", "Beijing Guide" and other guiding documents , Pointed out the development direction for the construction of new engineering, that is, in higher education, it is necessary to carry out relevant research and practice around the new concept, new structure, new model, new quality, and new system of engineering education reform. This is also the current reform in the field of higher engineering education. important content [2].

Engineering education professional certification is an important foundation for achieving international mutual recognition of engineering education and international qualifications of engineers[3], and its core is to confirm that engineering graduates meet the established quality standards recognized by the industry. In 2016, my country became a full member of the "Washington Agreement"[4], which indicates that my country's engineering education quality evaluation standards have been recognized by international counterparts. Engineering education professional certification is playing an increasingly important role in improving the quality of engineering education in my country's colleges and universities [5].

The "Electric Machinery" course is an important professional core course for electrical majors in colleges and universities. The course is characterized by strong theory, abstract concepts, and close connections with engineering practice. Under the new situation of deepening the reform of undergraduate education and teaching in higher education, the research and practice of curriculum ideology and politics with the background of engineering education professional certification has important practical significance, and it is also a new opportunity for continuous advancement and reform of this course with the goal of building a first-class curriculum and inevitable requirements.

\section{PROBLEMS AND CHALLENGES FACED IN CURRICULUM IDEOLOGY BY ENGINEERING MAJORS}

For a long time, both teachers and students have believed that the main tasks of ideological and political courses, and that it has nothing to do with professional courses. This 
phenomenon is more common in engineering majors with particularly strong professionalism. This phenomenon is mainly due to the following three reasons: First, most colleges and universities do not pay much attention to curriculum ideology and politics in engineering education, thinking that this is the work of the instructor or class teacher, and has nothing to do with professional teachers; second, most teachers have light The problem of ideological and political emphasis on professionalism. I cannot deeply understand the connotation and extension of ideological and political affairs. I think that professional knowledge education is my own job. Even some professional teachers lack ideological and political quality. So in the process of ideological and political education, there are frequent cognitive misunderstandings; Finally, due to the heavy professional knowledge and the severe employment situation, college students only pay attention to the learning of professional knowledge and technical skills. They have insufficient understanding of ideological and political education, and think that ideological and political education is optional, so they are not active in learning ideological and political courses. All causes education courses cannot be a good practice of ideological and political course.

In fact, college professional teachers have a natural advantage in ideological and political education, and professional teachers should be the main force in curriculum ideological and political education.

As an important member of the ideological and political education of college students, professional course teachers are the core team of the ideological and political construction of college courses. They are not only different from counselors, class teachers, ideological and political theory teachers, and political workers. In the course teaching and experimental links of professional courses, teachers will not directly instill ideological and political views, ideal values and beliefs, etc., to college students. Instead, they will have a certain degree of ideological and political quality through the implicit penetration of the classroom and the subtle influence of teachers' words and deeds. Impact. These constitute the unique advantages of the professional teacher group [7].

The recessive education method has become another important way of ideological and political education for college students. As the main force of recessive ideological and political education, professional course teachers should actively infiltrate ideological and political elements into professional courses and give full play to the hidden education function of professional courses., Educate and guide universities to become talents through curriculum ideological education.

To realize the implicit ideological and political education for college students, teachers of professional courses must have the following abilities: First, they must master and learn professional knowledge, be able to penetrate the past and the present, and connect with current affairs, so as to combine history and reality in the classroom to analyze current political hot spots And social mentality; secondly, they have good analytical skills in majors and national events, and can guide college students to understand themselves and realize their personal values; thirdly, professional courses are major courses for college students to enter colleges and universities. The sense of mystery and the sense of admiration for professional teachers will make professional teachers have an invisible demonstrative influence on students in their words and deeds. Finally, professional teachers should innovate the teaching methods of courses and use the methods of presenting and on-site perception to imply ideological and political education. This requires professional teachers to improve themselves and innovate continuously.

At the same time, the number of professional teachers in colleges and universities accounts for about $80 \%$ of the total number of teachers, and the professional class hours of each major account for about $80 \%$ of the total class hours. This data fully proves that professional teachers are the group with the longest contact with college students and the widest space., Is also the group that has the greatest impact on the words and deeds of college students. They will be the main force in the future colleges and universities to implement the task of fostering people. It can be seen that the position of professional teachers in the process of "full-staff education" is very important. We must firmly grasp the important part of professional teachers. In the process of fostering people, we must see the importance of professional courses. , Strengthen the guidance of professional teachers, promote professional teachers to do a good job in classroom guidance, answer questions, lead by example, teach by example, combine the characteristics of the times, professional characteristics, and student characteristics to prescribe the right medicine to meet the growth and expectations of college students.

\section{REFORM OF IDEOLOGICAL AND POLITICAL CONTENT IN THE COURSE "ELECTRIC MACHINERY"}

The educational goals of the "Electric Machinery" course are as follows: integrate the relevant content of ideological and political education into the teaching of classroom knowledge, and use the method of subject integration to achieve the purpose of ideological and political education. Through value guidance, the goal of "curriculum education" is achieved. The three-view education, the Chinese dream, and the core values of socialism in the ideological and political education are related to the professional ethics and dedication in the "Electric Machinery" course, so that students are influenced by mainstream values in a subtle way. Strive to achieve the talent training goal of "global vision, family and country feelings, innovative spirit, and professionalism". Guided by the socialist ideology with Chinese characteristics in the new era, we will cultivate students' pursuit of true knowledge through practice, cultivate a rigorous learning atmosphere, establish a correct outlook on life and values, and strengthen the learning of professional knowledge as the era $\mathrm{s}$ responsibility, historical mission and 
dedication. In the era, we have made due contributions to the construction of socialism with Chinese characteristics and laid a good professional ethics for future technical work related to electrical engineering and other fields. In the course of curriculum construction, the reform of curriculum ideological and political content can be carried out from the following aspects:

\subsection{Pursue Moisturizing Things Silently in the Concept of Curriculum Construction}

As a professional basic course, it is necessary to complete the recognition education of socialist core values on the basis of cultivating students' attention and interest. Let students identify with the theories, systems and values of socialism with Chinese characteristics in the new era, understand the core values of socialism; understand national conditions and social conditions, safeguard national interests, and have a sense of responsibility to promote national rejuvenation and social progress. While teaching knowledge, teachers should also explain the logic, spirit, value, thought, art and philosophy behind the knowledge, and effectively convey the correct value pursuit and ideals and beliefs to students in the form of "moisturizing things without sound".

\subsection{Highlight Cultivating Virtues and Morality in the Content of the Curriculum}

It must not only reflect the difference from the ideological and political theory course, but also show the connotation of ideological and political education, embody the core content of political identity, national consciousness, cultural self-confidence, civic personality, etc., and highlight the fundamental task of establishing morality; need to pass re-courses Zhong added ideological and political elements to cultivate students' overall strategic awareness of China's future; cultivate students' ability to think about the development goals of human society from the complex and changeable objective reality; cultivate students' patriotism and a strong sense of pride.

\subsection{Optimize Ideological and Political Elements in the Curriculum Construction Standards}

Optimize curriculum construction standards and teaching methods, highlight ideological and political education elements, and allow students to learn the importance of electrical machinery in the national economy through curriculum learning; grasp the complex electrical engineering issues, clarify development goals, implement the concept of sustainable development, and advocate Common development; understanding the important significance of the research and use of electric motors to enhance the country's comprehensive national strength.

\subsection{Promote Outstanding Cases in the Results of Curriculum Construction}

Through curriculum reform, provide a certain degree of display of curriculum ideological and political reform results, including design plans and implementation results of curriculum ideological and political reform cases; produce complete teaching micro-videos that reflect the core elements of "curriculum ideological and political", and reform cases or teaching The micro-video upload course website can be put into use during the course of teaching. At the same time, encourage students to share micro-videos with positive energy.

\subsection{Improve Overall Quality in the Curriculum Construction Guarantee System}

According to the orientation of the school and the characteristics of the training of the teaching team, improve the overall quality of the practical teaching team, encourage the teaching team to improve the professional quality, practical ability and teaching level by going abroad for further study, temporary training, degree study, special training, etc., to form an advanced concept and experience Abundant, capable, diligent in exploring and innovative "dual-teacher" practice teaching team.

\section{EXPLORING THE IDEOLOGICAL AND POLITICAL ELEMENTS IN THE COURSE "ELECTRIC MACHINERY"}

(1) The introduction part describes the country's outstanding achievements in the development of electric motors and power technology, and guides students to objectively understand the country's contributions and achievements in the world's power development, not to be scornful or complacent, but to solidly advance the country's basic research step by step.

(2) The basic concept and development history of "Electric Machinery", for China's high-speed railway Fuxing, shared stories of experts in the field of electrical engineering overcoming scientific research problems, and encouraged students to work hard and carry forward the spirit of innovation in future studies.

(3) In response to the power outage in Jiulong Lake, it was emphasized that the world cannot do without our electrical engineering and the hard work of electrical engineers. Motors and electrical appliances play a very important role in the national economy.

(4) Taking the "China Speed" of Leishen Mountain and Vulcan Mountain in the 2020 anti-epidemic process as typical cases, leading students to discuss "What role does the motor play in the rapid construction and efficient operation of Leishen Mountain and Vulcan Mountain? "This further aroused the students to think about the contribution of the knowledge learned in professional courses to the current epidemic prevention and control. 
(5) Taking the rapid development of high-speed rail as the starting point, raise questions to students and initiate discussions: "How much do students know about the 'power heart' of high-speed rail?" "In September 2019, China independently developed a speed of 400 kilometers per hour. The TQ-800'permanent magnet high-speed rail' motor fills the domestic technical gap. Which type of motor does it belong to in the "Electric Machinery" course in terms of operating principle? It stimulates students' interest in the course of "Electric Machinery".

(6) In the grid connection experiment of the synchronous generator, it is necessary to adjust the frequency and voltage of the synchronous generator to make it the same as the frequency and voltage of the grid, and then find the moment when the phase is the same as the grid to switch on and connect to the grid, which reflects the students' needs To become a member of the collective, you must meet the requirements of the collective and adapt to the development of the collective; active and power adjustments are based on the requirements of the power grid for active and reactive power adjustments, reflecting that a member of the collective must obey the collective arrangements. According to the collective arrangements, Conform to the collective benefit and make your due contribution.

(7) The asynchronous motor is mainly different from the transformer and the synchronous motor in the operating characteristics of the asynchronous motor, that is, the relationship between the characteristics of the asynchronous motor and the output power, and the characteristics increase with the output, but the characteristics change when the output is too large. It reflects that we need to work hard to contribute to society, and our lives will be more glorious, but if our load is greatly exceeded, efficiency will decrease, indicating that everyone needs to adjust their status according to their actual situation, and strive to work in the best posture.

(8) When explaining the rated voltage of the equipment, introduce the Xinjiang Changji-Anhui Guquan project that has been successfully transmitted in my country. This is the world's first $\pm 1100 \mathrm{kV}$ UHV DC transmission line independently designed and constructed by China to cultivate students' patriotic feelings and national pride, but also the craftsman spirit of pursuing excellence.

(9) When conducting electrical experiments, emphasize the accuracy and safety of wiring. This is because to improve reliability is to reduce economic efficiency. On the one hand, it is necessary to cultivate students' philosophical thinking of "giving and gaining"; on the other hand, it is necessary to guide students to find the key points of the problem and analyze the specific problems in detail; The painful experience and lessons of trips, fires and explosions warn students that their lack of responsibility will bring irreversible harm. The emotional and psychological influence of students will cultivate students' excellent professional level, sense of social responsibility, and professional ethics.

(10) In view of the current situation of large-scale smog in East China, especially in winter, the sky is difficult to distinguish, emphasize the necessity of developing new energy power generation, analyze the advantages of various wind power and photovoltaic power generation, and guide students in their careers, And at the same time advocate green travel to students, and everyone is responsible for energy conservation and environmental protection.

\section{CONCLUSION}

At present, the form of higher education in our country is complicated. The background of new engineering and professional education certification requires colleges and universities to not only root professional basic knowledge, but also cultivate students' craftsmanship and humanistic qualities when cultivating socialist successors. This is both an opportunity and a challenge.

Taking the course of "Electric Machinery" as the carrier, without undermining professional knowledge, professional skills, and professional practice level, it integrates ideological and political education in an all-round way, including noble professional ethics, solidarity, cooperation, honesty and trustworthiness, style, meticulous and craftsman spirit of excellence. It breaks the traditional teaching conventions, changes the teaching concept, and constructs a teaching link with ideological and political education connotation and innovative elements, allowing students to consciously shape their outlook on life and values while focusing on professional knowledge learning. It provides new ideas for engineering professional curriculum education. Starting from the ideological roots, it strives to cultivate social attention builders and successors with Chinese characteristics.

\section{ACKNOWLEDGMENT}

The authors would like to appreciate all the editors and reviewers for improving the quality of this article. This work was supported by the Xijing University Key Curriculum "Electric Machinery"(XJDZKC20014), and Xijing University "one teacher and one excellent course" (project in 2019).

\section{REFERENCES}

[1] Zou Lingjun. The design and implementation of one-stop campus service platform on the mobile terminal of colleges and universities under the smart campus [J]. Fujian Computer, 2019, 35(2): 80-83. (In Chinese)

[2] Liu Dongying. Exploration of the humanistic quality education of college students under the background of new engineering disciplines [J]. China University Teaching, 2018, 11: 26-29. (In Chinese) 
[3] China Engineering Professional Certification Association. General Standard [S]. (In Chinese)

[4] Zhang Haiyun, Li Zhiyong, etc. Construction of innovative curriculum system for mechanical design and manufacturing and automation based on engineering professional certification $[\mathrm{J}]$. Education and Teaching Forum, 201935: 99-100. (In Chinese)

[5] Gu Yongan. Applied undergraduate professional clusters: an important breakthrough for the transformation and development of local universities [J]. China Higher Education, 2016 (22): 35-38. (In Chinese)

[6] Wang Yuenan. Exploration and practice of integrating "power supply and distribution engineering" into "curriculum ideological and political" [J].

Heilongjiang Education, 2020 (12): 11-12. (In Chinese)

[7] Luo Zhongyou. The advantages and significance of the ideological and political practice of professional teachers in colleges and universities [J]. China Higher Education, 2016 (6). (In Chinese) 